The Overseas Desk will be publicised amongst Members of the College who are not resident in Great Britain and Ireland and we hope they will make comments. It would be important to find out what the needs of such Members are, and how they could make use of the Overseas Desk and through it the College, to a greater extent. There may be specific needs for particular countries that the College would be able to meet.

There may well be scope for College meetings to be held overseas. So far there has been a College Regional Meeting held in Pakistan, and a Joint College Meeting held in Bordeaux. There may be scope for the establishment of 'chapters' of the College in other parts of the world.

Should there be a College Overseas Division or Advisers in a formal sense? There is no obvious advantage in such an arrangement, and some disadvantages: there is, for instance, a risk of setting up a parallel group within a country which was seen to be in some respects in competition with the local psychiatric organisation. It would be very difficult to combine the varying needs and interests of different countries. We are, of course, dependent on the recommendation for overseas members for Fellowship upon the existing Fellows in each country.

\section{(4) Psychiatric training overseas}

Especially in those countries with traditional links with the College, there may be scope for the College to be useful in enabling Members of the College resident in this country to teach and take part in other educational activities overseas. This could involve examining and approving training, and, of course, these three aspects of teaching, examining and approving psychiatric educational facilities already takes place to some extent.

For instance, the College has recommended external examiners to take part in local postgraduate psychiatric examinations, in Singapore and Sri Lanka. Also, examiners from abroad involved in setting up or improving local examinations have, on occasions, observed the examination procedures and standards of the College.

Many overseas countries are hard pressed to pay for a teacher or a trainee to come to the UK for a period of academic refreshment or training in research. The College and the overseas country might try to raise money, from an external source, to support such schemes. We hope to initiate such a scheme with our colleagues in Pakistan with the help of a pharmaceutical company.

\section{(5) Matters of psychiatric concern in other countries}

There are a number of other areas in which the College would have an interest and involvement in psychiatric practice in other countries. Some of these matters will be dealt with already in other Committees, Working Parties and Groups within the College, and are not the concern of the Overseas Desk.

These are at the moment only ideas and suggestions. To convert them into reality, Members and Fellows of the College, and especially those overseas, should let us know which of these options they regard as important and what other aspects of the functions of the College could be used more effectively if their individual needs and local situations were taken into account.

Professor ANDrew Sims

Dean

\title{
Overseas Page
}

At any one time about $25 \%$ of our members are resident overseas, many returning to their home centres after training in the United Kingdom.

Some of them have suggested that it would help them to keep in touch with the remaining members of the College if there were a page of the Bulletin devoted to contributions from overseas colleagues. This suggestion was welcomed and agreed by the Executive and Finance Committee. Members residing abroad are now invited to send letters, articles or other material for this purpose, addressed to the Editors of the Bulletin.
Professor R. G. Priest Registrar 